\title{
СПЕЦИФІКА УСНОГО ПОСЛІДОВНОГО ПЕРЕКЛАДУ
}

Послідовний переклад - ие вид перекладу, при якому перекладач чекає, коли оратор зробить паузу у своїй промові, інтерпретує сказане, а потім слухає мовия $і$ чекає, коли він знову зробить паузу для здійснення перекладу. Частота пауз дуже варіюється, але здебільшого вони робляться після завершення кількох речень. Якщо оратор розмовляє протягом більш тривалого періоду часу, перекладач здебільшого робить нотатки для точного перекладу.

Послідовний переклад охоплює практично всі види мовленнєвої діяльності: продуктивні (говоріння і письмо) і рецептивні (слухання $і$ читання). Прочес усного послідовного перекладу відрізняється від прочесу письмового чи синхронного. У статті охарактеризовано послідовний переклад як різновид усного перекладу; описано його особливості; досліджено модель і приничии послідовного перекладу; наведено особливості його здійснення та проаналізовано процес усного послідовного перекладу, який непропориійно поділено на стадію прослуховування, стадію розуміння дискурсу та процесу формування мови.

Автор дослідницької роботи виокремлює основні навички, необхідні для послідовного перекладу, наголошуючи на здатності емоиійно передавати отриману інформацію. У статті наголошується на важливості першого етапу перекладу (семантичного сприйняття перекладу), від якого залежить повнота та точність послідовного перекладу. Розглянуто основні типи послідовного перекладу та їх функиіональні особливості. Проаналізовано основні стратегії та тактики послідовного перекладу залежно від тексту оригіналу та иільової аудиторії.

Дослідницька робота зосереджена на вимогах до усного послідовного перекладу. Автор роботи аналізує індивідуальні навички та вміння перекладача під час послідовного перекладу. Також розкрито основні знання, вміння та навички, необхідні для здійснення усного послідовного перекладу.

Ключові слова: усний переклад, послідовний переклад, технологія, особливості, навички.

Liudmyla HONCHARENKO, orcid.org/0000-0002-9541-952X

Candidate of Philological Sciences, Associate Professor at the Department of Romano-Germanic Philology and Translation from German Petro Mohyla Black Sea National University (Mykolaiv,Ukraine) stotskaya07@rambler.ru

\section{SPECIFICS OF ORAL AND SEQUENTIAL TRANSLATION}

Consecutive interpreting is a type of interpreting in which interpreter waits for the speaker to make a pause in their speech, interpret what has been said and then listen to the speaker and wait for them to make a pause again to interpret. The frequency of pauses varies greatly but pauses are usually made after completing a few sentences. If the speaker is talking for a longer period of time, interpreter usually makes notes in order to render an accurate translation.

This article describes the sequential translation as a kind of oral translation. Features of its implementation are presented. The model and principles of sequential translation are investigated. The research paper describes the peculiarities of its implementation are given and the process of verbal consecutive translation, which is disproportionately divided into the stage of audition and the stage of understanding the discourse and the process of language generation, is analyzed. The author of the research paper singles out the basic skills necessary for carrying out consecutive translation, emphasizing the ability to emotionally transfer the information received.

The article emphasizes the importance of the first stage of translation (semantic perception of translation), on which the completeness and accuracy of consecutive translation is dependent. The main types of consecutive translation and their functional features are considered. The basic strategies and tactics of the consecutive translation depending on the text of the original and the target audience are analyzed.

The research paper focuses on the requirements for consecutive interpreting. The author of the research paper analyzes the individual skills and abilities of the interpreter during consecutive translation. The basic knowledge, skills and abilities necessary for the implementation of oral consecutive translation are revealed.

Key words: oral translation, sequential translation, technology, features, skills. 
Постановка проблеми. Базовим для засвоєння інших видів усної перекладацької діяльності вважається усний послідовний переклад. У процесі професійної підготовки перекладачів необхідно включати у зміст навчання всі модифікації цього виду, а саме вправи в односторонньому, двосторонньому, повному, скороченому, абзацно-фразовому перекладі. Однак більше уваги необхідно приділяти істинному послідовному перекладу із записом у різних ситуаціях із застосуванням сучасних технічних засобів (телефонний переклад, телепереклад, переклад із мультимедійною презентацією).

Під послідовним перекладом науковці розуміють професійний вид перекладацької діяльності, який передбачає усний переклад на слух із записами (Бенедиктов, 1972; Нелюбин, 2003; МиньярБелоручев, 1969).

Аналіз досліджень. Вивченням усного перекладу в різних його виявах займалися вчені Е. Гончаренко, Д. Жиль, О. Каде, С. Каліна, В. Куц, М. Вербицька, Г. Чернов та інші. Серед дослідників, які займалися проблематикою перекладу, зокрема послідовного, варто виділити Т. Андрієнка, В. Виноградова, А. Козак, І. Котлярову, А. Кочубей, О. Попова, О. Селіванова.

Мета статті - комплексна характеристика послідовного перекладу як базового виду усної перекладацької діяльності.

Виклад основного матеріалу. Вперше перехід до істинного послідовного перекладу стався в межах Паризької мирної конференції 1919-1920 років, коли французька втратила монополію єдиної дипломатичної мови. Однак місцем найбільшого розквіту усного послідовного перекладу виявилася Ліга Націй (1919-1942 роки), на засіданнях якої передбачалися дві робочі мови: французька та англійська, а промови ораторів не переривалися перекладом, чергуючись із ним.

Специфіку усного послідовного перекладу визначають задіяні види мовленнєвої діяльності: аудіювання, думання, запис, прочитання запису i говоріння. Цей ланцюжок видів мовленнєвої діяльності співставний із фазами когнітивної моделі перекладу Д. Жиля: сприйняття на слух, аналіз і зберігання інформації вихідного повідомлення, вилучення екстралінгвістичної інформації із довготривалої пам'яті, здійснення запису; вилучення інформації 3 оперативної пам'яті, прочитання запису і створення повідомлення мовою перекладу (Жиль, 2009). У такому випадку доцільно розглянути психологічну модель послідовного перекладу.

У результаті сприйняття повідомлення на слух мовою оригіналу воно підлягає кодуванню. Одночасно 3 цим на основі розумових операцій аналізу і зіставлення перекладач веде запис, який супроводжується відбором інформації 3 точки зору іiі змістовної важливості, винятковості, мнемічної ілюстративності. Оскільки усне мовлення надлишкове, а швидкість мислення перевищує швидкість говоріння, то розуміння смислового сегменту вихідного повідомлення випереджає його завершеність. Цьому сприяє $\mathrm{i}$ механізм ймовірного прогнозування. Накопичений «запас часу» дозволяє перекладачеві викликати 3 довготривалої пам'яті адекватний прийом запису, знак, який найбільш яскраво ілюструє зміст висловлювання.

Необхідно зазначити, що сприйняття на слух триває, оскільки надходить новий сегмент інформації. Завдяки переключенню та обсягу уваги інформація залишається в оперативній пам'яті, співвідноситься 3 попереднім сегментом і фіксується. Після завершення звучання вихідного повідомлення у розпорядженні перекладача знаходяться дві програми, одна з яких - у внутрішній мові як результат внутрішнього кодування, а інша - у вигляді перекладацької семантографії, яка є результатом зовнішнього кодування (Алікіна, 2006).

Із терміналу пам'яті інформація надходить в еффекторний термінал, де реалізується формулювання промови мовою перекладу. Сприйняття на слух при прочитанні запису змінюється зоровим сприйняттям, активізуються операції синтезу та узагальнення, концентрація уваги спрямована на коректне, логічне оформлення мови. При цьому здійснюється операція порівняння зі слідами внутрішньої програми, яка зберігається в оперативній пам'яті.

Перш ніж сегмент повідомлення на мові перекладу буде вимовлено, усі зазначені вище механізми декодують інформацію у внутрішній мові, тобто породження перекладу на основі прочитання перекладацької семантографії супроводжується ії внутрішнім декодуванням (Алікіна, 2006). Можна вважати, що облік специфічних характеристик діяльності усного послідовного перекладу i психологічних механізмів, які забезпечують його здійснення, необхідний для визначення професійно-значущих якостей перекладача. До них відноситься хороший слух, швидка реакція, здатність до концентрації уваги, розвинена оперативна пам'ять, здатність одночасно виконувати різні дії, психологічна стійкість.

Крім психологічного змісту, усний послідовний переклад характеризується низкою технічних, стилістичних, змістових, локально-темпоральних особливостей. До темпоральних характеристиках усного послідовного перекладу необхідно віднести однократність і дискретність сприйняття інформації відносно тривалого звучання вихідного фрагменту, залежність від просодичних характе- 
ристик мови оратора, виконання в реальному часі, неодночасність повідомлень вихідною мовою та мовою перекладу і одночасне виконання різних за модальністю мовних дій (аудіювання та запис, прочитання запису і відтворення повідомлення).

Синхронність аудіювання та фіксації відносна, оскільки перекладач починає записувати тільки тоді, коли йому стає зрозумілий сенс. Швидкість мови перекладача залежить від мови оратора: при швидкому темпі виступу перекладач говорить так само швидко, при уповільненому темпі вихідної мови переклад вимовляється в більш швидкому темпі.

Усний послідовний переклад здебільшого спрямований на переклад усної публічної промови, яка, за словами I. Алексєєвої, характеризується такими рисами: спрямованість на повідомлення нового знання, закінчена форма зі стрункою структурою, особливі етичні формули, нормативність мовлення, різного роду повтори, індивідуально-авторський стиль, імпровізовані вкраплення, які навіть за умови підготовленості тягнуть за собою незакінчені і нелогічні фрази. Особливі труднощі для перекладача, на думку автора, несе емоційна інформація, передана емоційно-забарвленою лексикою, яка часто втрачається при перекладі (Алексєєва, 2008: 113).

Вимоги до послідовного перекладу можна описати так: коли мовець перестає говорити, перекладач надає частину повідомлення або все повідомлення. Якщо оратор говорить речення чи два, то перекладачу легше перекладати. Якщо ж спікер розмовляє довше, перекладач повинен робити нотатки, щоб точно передавати повідомлення. Оратор може розмовляти протягом п'яти хвилин перед тим, як зробити паузу.

Послідовний перекладач повинен мати чудову пам'ять, крім вільного володіння мовами джерел і цільової мови. Такий перекладач потребує чудових навичок нотування. Спеціалісти використовують спеціальну нотну систему для позначення слів, які позначають наголос, заперечення, послідовність. Здебільшого від послідовного перекладача вимагається відтворювати, а не запам'ятовувати суть виступу. Замовник повинен ретельно проінформувати перекладача перед початком роботи. Останній повинен мати довідкову інформацію про доповідача, тему заходу, компанію та продукцію. Важливо надати перекладачеві проекти виступів і коротко проінформувати його, якщо $є$ спеціальна лексика, термінологія та інша життєво-важлива інформація, яку вимагає клієнт чи спікер. Чим більше довідкової інформації отримує перекладач, тим точнішим буде переклад.
Будь-який вид діяльності вимагає адекватної оцінки його якості. Майбутній перекладач повинен мати повноцінне уявлення про критерії якості перекладу, що дозволить йому оцінювати як власну роботу, так і роботу своїх колег. Категорія якості активно обговорюється в сучасних перекладознавчих дослідженнях. В останнє десятиліття активно розвивається такий розділ перекладознавства як наукова критика перекладу. Вітчизняні дослідники здебільшого піддають критиці письмовий переклад (Н. Галь, Н. Гарбовський, В. Комісарів, Л. Латишев, А. Федоров, К. Чуковський, А. Шевнін), тоді як у закордонному перекладознавстві більше уваги приділяється усному перекладу (H. Barik, H. Bühler, I. Kurz, B. MoserMercer, B.C. Ng).

Як справедливо зазначає Д. Жиль, проблема оцінки якості перекладу має подвійне значення: прагматичне і педагогічне. Споживач перекладацьких послуг спрямований на задоволення своїх потреб за прийнятною ціною, що передбачає відповідність якості певним стандартам. Переклад же як у реальній, так і в навчальній ситуації $\epsilon$ процесом формування перекладацької компетентності (Жиль, 2009).

Висновки. Можна констатувати, що під час здійснення послідовного перекладу першим етапом діяльності перекладача є смислове сприйняття повідомлення, яке він чує, та фіксація потрібної інформації. Другий етап - розшифрування фахівцем своїх записів і передача повідомлення мовою перекладу. Записи потрібної інформації у послідовному перекладі виконують роль допоміжного засобу. Під час оформлення перекладу записи допомагають спеціалісту відновити в пам'яті те, що сприймалося раніше, а процес запису здебільшого стимулює інтелектуальну активність і активізує процес запам'ятовування. Отже, для здійснення послідовного перекладу необхідним є вміння аудіювання та оформлення перекладу в усній формі.

На думку А. Полікарпова, напрямами аналізу дискурсу усного послідовного перекладу є чотири компоненти: усно-породжувана мова оратора, сприйняття усно-породжуваної мови перекладачем, «відтворювана» усно-породжувана мова перекладача, сприйняття усно-породжуваної мови перекладача (Полікарпов, 2008). Вивчення усіх перерахованих вище компонентів усного дискурсу «вимагає серйозного психолінгвістичного опису, в тому числі проведення експериментальних досліджень при кількісній та якісній обробці записів усних текстів-перекладів» (Полікарпов, 2008: 145) i може бути розглянуто в якості перспективи. 


\section{СПИСОК ВИКОРИСТАНИХ ДЖЕРЕЛ}

1. Алексеева И. С. Текст и перевод. Вопросы теории. Москва : Междунар. отношения, 2008. 184 с.

2. Аликина Е. В. Переводческая семантография. Москва : Аст: Восток-Запад, 2006. 192 с.

3. Бенедиктов Б. А. Общие и темпоральные особенности устного перевода и владения языками : дис. д-ра психол. наук: 19.00.01. Ленинград, 1972. $331 \mathrm{c}$.

4. Миньяр-Белоручев Р. К. Пособие по устному переводу (Записи в последовательном переводе): для институтов и факультетов иностранных языков. Москва : Высшая школа, 1969. 191 с.

5. Нелюбин Л. Л. Толковый переводоведческий словарь. Москва : Флинта, 2003. 320 с.

6. Поликарпов А. М. Синтаксические особенности устнопорождаемой речи и перевод. Теория и практика перевода и профессиональной подготовки переводчиков. Устный перевод : материалы Междунар. науч-метод. конф., 30 нояб. - 02 дек. 2007 года. Пермь, 2008. С. 131-148.

7. Gile D. Basic concepts and models for translator and interpreter training. Amsterdam / Philadelphia : John Benjamins Publishing Company, 2009. 284 p.

8. Bühler H. Linguistic (semantic) and extra-linguistic (pragmatic) criteria for the evaluation of conference interpretation and interpreters. Multilingua, 1986. № 5(4). P. 231-235.

9. Kurtz I. Conference interpreting: quality in the ears of the user. Meta, 2001. Vol. 46(2). P. 394-409.

10. Moser-Mercer B. Quality in interpreting: some methodological issues. The Interpreters' Newsletter, 1996. № 7. P. 43-55.

11. $\mathrm{Ng} \mathrm{B.} \mathrm{End} \mathrm{users'} \mathrm{subjective} \mathrm{reaction} \mathrm{to} \mathrm{the} \mathrm{performance} \mathrm{of} \mathrm{student} \mathrm{interpreters.} \mathrm{The} \mathrm{Interpreters'} \mathrm{Newsletter,} 1992$. Spec. issue 1. P. 35-41.

\section{REFERENCES}

1. Alekseeva Y. S. Text y perevod. Voprosy teoryyi [Text and translation. Theory of issues]. Moscow : Mezhdunar. jtnoshenyya, 2008. 184 p. [in Russian].

2. Alykyna E. V. Perevodcheskaya semantografyya [Translation semantography]. Moscow : Ast: Vostok-Zapad, 2006. 192 p. [in Russian].

3. Benedyktov B. A. Obshchye y temporalnye osobennosty ustnoho perevoda y vladenyya yazykamy [General and temporal features of interpretation and language proficiency] : dys. d-ra psyhol. nauk: 19.00.01. Lenyngrad, 1972. 331 p. [in Russian].

4. Myn'yar-Beloruchev R. K. Posobyye po ustnomu perevodu (Zapysy v posledovatelnom perevode) dlya ynstytutov y fakultetov ynostrannych yazykov [Interpretation Manual (Recordings in Consecutive Translation): for Institutes and Faculties of Foreign Languages]. Moscow : Vysshaya shkola, 1969. 191 p. [in Russian].

5. Nelyubyn L. L. Tolkovyy perevodcheskyy slovar [Explanatory translation dictionary]. Moscow : Flynta, 2003.320 p. [in Russian].

6. Polykarpov A. M. Syntaksycheskyye osobennosty ustnoporozhdaemoy rechy y perevoda [Syntactic features of oral speech and translation]. Teoryya y praktyka perevoda y professyonalnoy podhotovky perevodchykov. Ustnyy perevod: materyaly Mezhdunar. nauch-metod. konf., 30 noyab. - 02 dek. 2007. Perm, 2008. P. 131-148 [in Russian].

7. Gile D. Basic concepts and models for translator and interpreter training. Amsterdam / Philadelphia : John Benjamins Publishing Company, 2009. 284 p. [in English].

8. Bühler H. Linguistic (semantic) and extra-linguistic (pragmatic) criteria for the evaluation of conference interpretation and interpreters. Multilingua, 1986. № 5(4). P. 231-235 [in English].

9. Kurtz I. Conference interpreting: quality in the ears of the user. Meta, 2001. Vol. 46(2). P. 394-409 [in English].

10. Moser-Mercer B. Quality in interpreting: some methodological issues. The Interpreters' Newsletter, 1996. № 7. P. 43-55 [in English].

11. $\mathrm{Ng} \mathrm{B}$. End users' subjective reaction to the performance of student interpreters. The Interpreters' Newsletter, 1992. Spec. issue 1. P. 35-41 [in English]. 